\title{
Dansk serielyrik
}

\section{Estetikteoretiske og litteraturhistoriske perspektiver på en poetisk strømning}

At relatere begreberne det serielle og serialisering til lyrikkens udvikling kan umiddelbart synes paradoksalt, hvis man tænker på, at få genrer har været omgærdet af så voldsom en aura af noget unikt og ophøjet som den poetiske. Man forbinder ofte det serielle og serialisering med noget populært og masseproduceret, der afvises på tærsklen til poesiens finere gemakker. En sådan afvisning har dog langtfra kunnet opretholdes i den ekspansive udvikling, som den poetiske genre har gennemgået frem til det 21. århundrede, og jeg vil her give et rids af, hvordan det serielle og serialiseringen har været markante i forhold til innovationen inden for moderne poesi. I forlængelse af dette vil jeg hævde, at man får et helt nyt perspektiv på lyrikhistorien, når man anlægger en serialitetsoptik, idet betydningen og forståelsen af begreber som digt, digtsamling, værk og forfatterskab ændrer sig.

Det skal indledende slåes fast, at begreberne det serielle og serialisering er beslægtede, men ikke synonyme. Mens kulturvidenskaberne anvender serialisering i relation til et litteratursociologisk perspektiv, hvor der sker en publisering og en distribution af et værk i mindre bidder over et forløb, så anvendes det serielle i æstetikken til at karakterisere en sideordnet og uafgrænset række af elementer i et værk.

Når vi taler om serialisering inden for litteratur, går man som regel tilbage til 1800-tallets engelske føljetonroman som udgangspunktet for den strøm af kulturprodukter fra det seneste århundrede, hvor et værk udgives i en ofte uendelig række dele. Ud fra et sådant perspektiv er serialisering udtryk for en kommerciel model, der propagerer en kompositionsform, en distributionsform og en forretningsmodel. Konsekvensen af dette er, at den enkelte episode i en serie mister sin aura som selvstændigt værk, og at serien som kontekst bliver den forståelsesramme, som en del fra en serie skal ses i forhold til. Umberto Eco opstiller i "Interpreting Serials" (1990) det tankeeksperiment, at man i år 3000 kun har én overleveret episode af tv-serien Columbo bevaret, og der opstår da den for os absurde refleksion over, hvordan man mon vil forstå denne episode uden resten af serien som kontekst (Eco 1990, 100). 
Det er en hovedpointe i det følgende, at de serielle strukturer med deres sideordnede og uafgrænsede karakter, som optræder i værker, kan knyttes til de serialiserede processer i masseproduktionens tidsalder og hermed udtrykker et opgør med det autonome og originale værk. Der rejses i serielyrikken et spørgsmål om, hvorvidt kunstværket - f.eks. digtsamlingen og digtet - har en autonom og original status, således som det har været hævdet i hovedparten af den moderne æstetik fra Kant, Hegel og romantikken over symbolismen til i dag. Blandt de første, der reflekterede kritisk over denne problemstilling, var Walter Benjamin, der i "Das Kunstwerk im Zeitalter seiner technischen Reproduzierbarkeit" (1936) har fokus på det faktum, at en række teknikker som foto, film og litografi har gjort det muligt at reproducere kunstværker, og at denne tendens - provokerende inkarneret med Marcel Duchamps readymades - har anfægtet forestillingen om det unikke kunstværk, der med Benjamins begreb har en særlig "aura". Om sidstnævnte begreb anfører Benjamin: "Hvad er aura egentlig? Et sælsomt spind af rum og tid: den enestående fremtoning af noget fjernt, hvor nær det end er" (Benjamin 1998, 73). Eller sagt på en anden måde: Det autonome værks "aura" er en tvivlsom metafysisk konstruktion.

Vigtigt er det imidlertid, at der også er andre kræfter på spil end de kommercielle, når en genre, der om nogen er omgivet af en ophøjet "aura", nemlig lyrikken, tydeligvis influeres af det serielle og serialiseringen. Og skal vi svare på, hvilke kræfter det drejer sig om, er det oplagt at se et sted hen, hvor der er ligeså stor modstand som der er fascination af den moderne kommercielle verden, nemlig i den avantgardistiske kunst og digtning. Avantgarden i mellemkrigstiden med bevægelserne dada, futurisme, imagisme og surrealisme bevægede sig således altid på en knivsæg i deres forsøg på, dels at være i opposition til den efter deres opfattelse snobbede og intetsigende, klassiske kunst og kultur, dels at forholde sig rebelsk og afvisende til den moderne kyniske og materialistiske kapitalisme.

I denne artikel vil jeg se nærmere på, hvordan det serielle og det serialiserede udtrykker sig på tre niveauer, nemlig henholdsvis det værkinterne, det enkelte værk som helhed og i en række af værker. Som det skal fremgå, dækker begrebet det serielle i højere grad de to første - mere værkcentrerede - niveauer, mens serialisering mest har relation til det sidste, hvor værkerne indgår i en serie - niveau. Der er dog tale om glidende kategorier på samme måde, som det kan være vanskeligt at sige, hvor grænserne går mellem en kapitalistisk masseproduktion og en avantgardistisk strategi, der f.eks. ifølge Peter Bürgers Theorie der Avantgarde (1974) har omsluttet hinanden i efterkrigstidens kunst.

\section{Serielyrik på det værkinterne niveau}

Ved serielle strukturer i et litterært værk forstår man, at en række elementer følger efter hinanden i en ikke-prioriteret og tilsyneladende tilfældig rækkefølge. I Unending Design. The Forms of Postmodern Poetry (1991) fremhæver Joseph M. Conte med udgangspunkt i læsninger af tekster af Robert Creeley, John Ashbery og Louis Zukovsky de serielle strukturer som et af de vigtigste træk ved "Postmodern Poetry". Serielle strukturer bør ikke forveksles med den klassiske brug af gentagelse inden for lyrikken. Generelt adskiller den serielle gentagelse sig fra den ældre ly- 
riks anvendelse af virkemidlet, idet der i ældre digtning er tale om et middel, der i form af et omkvæd eller en anaforisk struktur afspejler et stemningsmæssigt eller tematisk helhedspræg i teksten. De serielle strukturer inkarnerer derimod en modposition i forhold til de 'organisk opbyggede' digteriske værker. Det serielle princips essens er, at der ikke eksisterer et overordnet ideologisk princip eller en begrebsmæssig ramme som grundlag for sammensætningen af værkets elementer, men at disse derimod fremtræder i en vilkårlig orden. I Unending Design hævdes det, at man i de seneste års lyrik kan registrere et brud i forhold til romantiske og klassisk modernistiske værker med en tematisk motiveret, 'organisk' komposition:

Serial form offers itself as a distinct alternative to the organic sequence - a product of romanticism - whose development reflects the more leisurely pace and unitary quality of the nineteenth-century British house and garden or mountain lakes resort. (Conte 1991, 3)

Også Umberto Eco diskuterer i The Infinity of Lists (2009) det serielle som et dominerende kompositionsprincip inden for moderne litteratur. Ved en liste forstår vi vanligvis en række ord anbragt i en mere eller mindre ordnet rækkefølge, og det er oplagt, at lister er en vigtig underkategori i forhold til det serielle. I en skelnen mellem lister og serialitet generelt kan vi sige, at der i det første tilfælde er tale om en grad af orden, da selve listens mål jo er at huske og overskue et emne, mens det i det sidste tilfælde kan dreje sig om gentagelsesstrukturer i et monstrøst omfang. Med hensyn til lister skelner Eco imellem, hvad han kalder konjunktive lister, hvor sætningsleddene har et fællespræg, og disjunktive lister, hvor der er dissonans imellem leddene i listen. Ecos ræsonnement har en mere pessimistisk undertone end Contes, idet "listen" opfattes som en repræsentationsmodus, som udtrykker menneskets manglende evne til at forstå store ordener. Entydig positiv er derimod Jan Kjærstads "Oppramsningens mystikk" fra essaysamlingen Menneskets felt (1997). Kjærstad taler om, hvordan der i "listen" er tale om, at der "mellem de opstillede elementer opstår der en fornemmelse af en skjult sammenhæng". Og videre: "Som et fyrværkeri, noget kompakt, kan listen eksplodere i mange retninger."

Teoretisk har forestillingen om serielle strukturer nær forbindelse med grundtanken i dekonstruktionen og poststrukturalismen. Dette udgangspunkt har naturligvis forgrenet sig i en række forskellige tendenser i digtningen siden 1960'ernes slutning, men en central referenceramme for forståelsen af tekster tager afsæt i Jacques Derridas De la Grammatologie (1967), i hvilken det slås fast, at "skriften" - og dermed også de rytmiske former - "ophører med at betegne den ydre hinde, den upålidelige dobbeltgænger for en højerestående signifiant” (Derrida 1967, 47). I stedet er det afgørende i skriften, at de klanglige og rytmiske strukturer er betydningsskabende via det, Derrida kalder 'disséminationer'. Det er ikke en overordnet ide om digtets tema, stemning og 'verden', der styrer digtets forløb, men betydningsskreddene på det lydlige niveau.

Derridas argument findes i en række varianter hos teoretikere fra de følgende år, hvor en af de afgørende er Roland Barthes. Barthes taler analogt til Derridas 'disséminationer' om en 'paradigmatisk bevidsthed' i tekster. Han anfører: 
Uf The paradigmatic consciousness is a formal imagination; it sees the signifier linked, as if in profile, to several virtual signifiers which it is at once close to and distinct from; it no longer sees the sign in its depth, it sees it in its perspective; thus the dynamic attached to this vision is that of the summons; the sign is chosen from a finite organized reservoir, and this summons is the sovereign act of signification. (Barthes 1972, 210)

En videreføring af Barthes' forestilling om tekstens 'paradigmatiske bevidsthed' finder man hos Conte, der tilføjer:

6f The symbolic consciousness sees the sign in its "depth" and thus has a tendency to neglect form as a superficial concern in a work. But the paradigmatic consciousness sees the sign in its "profile" and thus pays particular constraints of the work; it is, after all, attention to the system. (Conte 1991, 41)

Modsat en afkodning af en betydningsmæssig ‘dybdestruktur’ skal læserens interesse altså være rettet mod tekstens overflade. Det gælder ikke om at finde en helhed, en overordnet mening eller en sandhed i teksten, men om at aflæse og erkende tegnenes arbitraritet og hengive sig til den flydende betydning. Målet med læsningen er at opleve den dynamik, der skabes i teksten i kraft af de forskellige tegns spil med hinanden.

I diskussionen af en sådan digtning kan det være formålstjenligt at skelne mellem to tendenser, der dog ikke i praksis nødvendigvis er skarpt adskilte. På den ene side har man en mere strukturelt og systemisk, skriftligt orienteret poesi, der opbygger værker efter serielle principper. På den anden side møder man en mere folkelig og mundtlig influeret tradition for anvendelsen af remser og 'beat'.

Den første type digte kan også kaldes 'sprogmaskiner'. Når denne betegnelse nævnes, falder tanken også på en bestemt digtsamling, nemlig Højholts Turbo (1968), der er et af de første eksempler på noget sådant i Danmark. En anden tekst af Højholt med en seriel struktur, hvor et narrativt-kausalt kompositionsprincip saboteres, stammer fra Groteskens område (1977) og bærer titlen "Kongen ankommer til cafeteriet ved havet". Vi hører om et cafeteria og en konge og har forventninger om en modernitetskritisk 'historie' om materialisme og åndløshed. Men alle forventninger skuffes, da sætningen "kongen ankommer til cafeteriet ved havet" begynder at køre i en båndsløjfe og gentages 12 gange i digtets afslutning, hvorved digtets referentielle funktion opløses.

Ser vi på den mundtlige remse-orienterede interesse for gentagelsen og det serielle manifesterer noget sådan sig især i Halfdan Rasmussens og Benny Andersens børnerim og fra 1960'erne i undergrundsbøger af digtere som Dan Turèll og Peter Laugesen. For Turèlls vedkommende møder man bl.a. en mængde remser i den 300 sider lange Karma Cowboy (1974). En typisk passage fra dette værk lyder: "Måger skræpper / Mensker knæpper / på ægte tæpper / Mensker knæpper / fra Rhinen til Djnepr // Alting hviler / Alting smiler / Alting sover / aldrig over."

I dansk digtning fra 1960'erne og frem til det nye årtusinde er det relativt sparsomt med serielt komponerede poetiske værker. Det serielle går ofte hånd i hånd med procedurale kompositionsprocesser, hvor en række tilfældige regler og prin- 
cipper bruges som ramme for den poetiske tekst. En afhandling, der diskuterer dette aspekt ved moderne poesi, er Joseph M. Contes tidligere nævnte Unending Design (1991). Når man ikke længere oplever, at en almen orden er mærkbar eller $\emptyset n s k e l i g$ i verden, indfører digteren i stedet, anfører Conte, en personlig orden, dvs. et bestemt system som kompositionel ramme for værket. I dansk sammenhæng er 1960'ernes systemdigtning et markant eksempel på denne strømning, og igennem sidste halvdel af det 20. århundrede har Inger Christensens det (1969) og Alfabet (1981) samt Klaus Høecks værker været typiske for denne tendens (jf. Larsen 2015, 53-61 og Larsen 2009, 329-336).

Mens de proceduralt orienterede systemdigtere som Høeck og Christensen imidlertid anvender andre kompotionsprincipper end det arbitrære og iterative, som er kernen i serielyrikken, så findes der også digtere, der er koncentreret om det serielle. Et eksempel på dette er Niels Frank, der i sin tidlige digtning med digtsamlingerne Øjeblikket (1985) og Digte i kim (1986) og den poetologiske essaysamling Yucatán (1993) forener den skriftbårne Højholt-linje med den remse-orienterede Turèll-linje med hensyn til serielle strukturer. Frank anfører i en reference til bl.a. minimalmusikken, at målet er at skabe en poesi, hvor ordene "udgør en hel lille tonerække som digtet gennemspiller igen og igen" (Frank 1993, 42).

I de sidste 20 års digitale tidsalder synes de serielle strukturer inden for moderne digtning at være eksploderet. En årsag til dette er uden tvivl, at brugen af computeren har gjort det let og ukompliceret at gentage elementer i digtningen. Blandt nordiske poeter fra de seneste år, der har brugt sådanne former, kan man fremhæve Malte Persson, Maja Lee Langvad, Martin Larsen, Peter Adolphsen, Ejler Nyhavn, Jonas Rolsted, Ida Börjel, Palle Sigsgaard, Pejk Malinowski, Audun Mortensen og Morten Søndergaard. Vi vil her se nærmere på fænomenet hos tre nordiske digtere, nemlig Ulf Karl Olov Nilsson (UKON), Audun Mortensen og Pejk Malinowski. I svenskeren UKON's digtsamling Barndomstolen (2009) lyder en passage fra et langdigt på 20 sider:

Uf Jag slog ihjäl honom för att han såg så oskyldig ut.

Jag slog ihjäl honom för att han såg så rik ut.

Jag slog ihjäl honom för att han såg så rädd ut.

Jag slog ihjäl honom för att han såg så dum ut.

Jag slog ihjäl honom för att han såg så asiatisk ut.

Jag slog ihjäl honom för att han såg så misstänksam ut.

Jag slog ihjäl honom för att han såg så slitstark ut.

Jag slog ihjäl honom för att han såg så modig ut.

Jag slog ihjäl honom för att han såg så algoritmisk ut.

Jag slog ihjäl honom för att han såg så kompetent ut.

Jag slog ihjäl honom för att han såg så hemlös ut.

Jag slog ihjäl honom för att han såg så kosmisk ut.

Jag slog ihjäl honom för att han såg så samarbetsvillig ut. (Nilsson 2009, 8-9)

Titlen på UKON's digtsamling er, som man bemærker, en neologisme, hvor udtrykkene "barndom", "domstol" og "barnstol" et svejset sammen i en subtil syntese, i 
hvilken der i høj grad - med Hugo Friedrichs yndlingsudtryk - er en "dissonantisk spænding" mellem det uskyldige stadie i menneskets liv og den rationelle samfundsregulerende jura. Det serielt strukturerede langdigt har en uhyggelig virkning på læseren, der er fanget i det syntaktiske system, hvor formuleringerne udvikler sig fra normalt menneskelige til de mest patologiske psykologiske udsagn, i hvilke enhver form for empati og medmenneskelighed er fraværende. Det absurde langdigt mimer på denne vis en nådesløs samfundsmæssig undertrykkelse og anonymisering. UKON-digtets serielle struktur udtrykker desuden en socialt kritisk vinkel, hvor der gives mulighed for at artikulere synsvinkler, synspunkter og stemmer, som normalt ikke har adgang til poesiens revir med dens høje stil og fokus på den unikke digterpersonligheds sjælelige problematikker.

En anden markant digter, der anvender serielle strukturer, er norske Audun Mortensen, der i 2009 udgav digtsamlingen alle_forteller_meg_hvor_bra_jeg_er_i_tilfelle_jeg_blir_det. Mortensens værk består i vid udstrækning af lister og serier. Man fornemmer helt ud i titlen med brugen af _, hvordan en dominerende inspirationskilde er internettet. Digteren udtaler da også i følgebrevet til sin digtsamling, at hans bog er for alle dem, der "hænger på internettet og lever et liv fyldt med filmcitater og facebook-opdateringer." Et uddrag af et serielt-proceduralt langdigt lyder:

6 diktet mitt føler seg som en 'gimmik'

diktet mitt lurer på om det vil få et nervøst sammenbrudd på lesesalen i løpet av uka diktet mitt lukker øynene og drømmer om å være på interrail i øst-europa diktet mitt er egentlig en e-post og vil aldri bli sendt diktet mitt vurderer å bruke utropstegn eller stor forbokstav eller la være å bruke anførselstegn for å gjøre seg 'utforutsigbart' og 'out of character'

diktet mitt er bekymret for at det ville ha blitt oppfattet som en 'gimmik' diktet mitt er bekymret for at dette også vil bli oppfattet som en 'gimmik' diktet mitt er egentlig en 'gimmik' som aldri vil bli sendt diktet mitt mistenker at forrige linje var en 'freudian slip' diktet mitt er egentlig en e-post som aldri vil bli sendt diktet mitt har egentlig lyst til å være 'chick lit' (Mortensen 2009, 122)

Teksten er med sin anafor "diktet mitt" principielt en uendelig række af refleksioner over, hvad et digt kan være. I pagt med med den humoristiske montagestil, som præger hele værket, er ovenstående tekst et eksempel på, hvordan Mortensen forholder sig ironisk til alle hævdvundne normer og værdier inden for poesien. Digte kan være alt fra 'e-post' og 'gimmik' til 'freudian slip' og 'chick lit'. Der er i den serielle struktur ingen værdihierarki og ingen prioriteringer, og det nærmeste, vi kommer en komposition, er linjernes stedvise kommentering af den netop afsluttede linje ("diktet mitt mistenker at forrige linje var en 'freudian slip"'). Teksten og alle_forteller_meg_hvor_bra_jeg_er_i_tilfelle_jeg_blir_det fuldbyrder på denne vis den popart-inspirerede bevægelse, som begyndte i 1960'erne med sit fundamentale opgør med den høje stil og den patosladede symbolistisk-modernistiske tradition.

Endelig er Pejk Malinowskis Den store danske drømmebog (2010) et gigantisk eksempel på et konceptuelt, serielt struktureret digt. Malinovski har sammenstyk- 
ket sit 233 sider lange værk af Google-søgninger på ordet "jeg drømmer" eller "jeg drømte". Resultatet er en seriel struktur, hvor opremsningerne og listen principielt er uendelig og forløber som i det følgende eksempel:

6f Jeg drømte at jeg fandt en scooter i vejkanten.

Jeg drømte at jeg ikke kunne sove. Kender du det?

Jeg drømte at Peter Belli og Master Fatman var en og samme person.

Jeg drømte at jeg skulle søle dig til i ketchup.

Jeg drømte at der stod nogen inde i mit sovekammer, jeg for op og syntes jeg så to skikkelser, som blev mere og mere gennemsigtige i det jeg stirrede.

Jeg drømte at jeg ikke havde mere neglelak på mine tånegle. (Malinowski 2010, 15)

Montagen består af citater af, hvad nogle tusinde personer har skrevet på internettet om, hvad de "drømte". Teksten giver et mangefacetteret billede af, hvad nutidens danskere har af fantasier, forestillinger, fobier, drifter, længsler og illusioner. Som i det ovenstående kan "drømme" spænde fra de mest banale foruroligende hverdagsforestillinger ("Jeg drømte at jeg ikke havde mere neglelak på mine tånegle") over erotiske excesser ("Jeg drømte at jeg skulle søle dig til i ketchup") til finurlige surrealistiske fantasier ("Jeg drømte at Peter Belli og Master Fatman var en og samme person"). Bogen indledes med et Walt Whitman-citat, der lyder: "Whoever you are, now I place my hand upon you, that you be my poem." Citatet af er velvalgt. Dels fordi Whitmans Leaves of Grass (1855) med sine katalogdigte er et af de første eksempler på en seriel komposition inden for moderne lyrik. Dels fordi man i sandhed må sige, at Den store danske drømmebog eliminerer lyrikkens traditionelle kendetegn med et centralt jeg, og at værket i stedet låner stemmer til et utal af subjekter.

I værket finder man sætninger med såvel høj som lav stil. Et eksempel på det første lyder: "Jeg drømte drømme, som kun en dreng med et intenst ønske kan drømme!" Et eksempel på det modsatte kan have følgende form, hvor ungdomsslang og emojis præger ortografien og retskrivningen: "JEG DRØMTE FAKTISK OGSÅ NOGET UHYGGELIGT I NAT. (Marylin ville ææde mig *tude*) - men så slog jeg ham cool. anyways ... DET VAR DIN SKYLD.” I nogle af sætningerne optræder der et kvindeligt subjekt: "Jeg drømte at jeg havde sex med min exmand, mens min søster talte i mobil i rummet. Drømte at vi bagefter gik ud i køkkenet hvor hans farmor stod." I andre optræder der utvetydigt et mandligt subjekt: "Jeg drømte at en køn pige spillede den af på mig." I atter andre møder vi subjekter, der kan stedfæstes til bestemte erhverv eller roller. Det gælder en golfspiller ("Jeg drømte først og fremmest om at få lov til at spille det næsten mytiske 16. hul”), en studerende ("Jeg drømte der startede helt vildt mange piger på matematik næste år") eller sågar en tegneseriehelt (“Jeg drømte jeg skulle på 'mission' med et par udvalgte fra 
Naruto"). Desuden er det karakteristisk, at søgemaskine-montagen består af tekster med mange forskellige genretilhørsforhold. Man møder avisnotitser ("Jeg drømte om at blive en ånd (Nikolaj, 25 år)"), en sang med guitar-becifringer ("Jeg drømte at vi mødtes her forleden $G$ på en øde landevej Am Og vi fulgtes mens jeg sagde at her ved broen C - D må vi nok gå hver for sig"), fortalte handlingsforløb ("Jeg drømte at jeg gik i skole, siger Amina med en lille skuffet stemme. Så vender hun sig om på sovemåtten og drømmer noget andet") og almene refleksioner ("Jeg drømmer ikke realistisk"). Endelig møder vi i Den store danske drømmebog ekspressive udtryk for frygt ("Jeg drømte at vores hus brændte"), længsel ("Jeg drømte at jeg var forelsket i to dejlige fyre, White Wolf og en som jeg ikke kan huske hvem er") og talrige andre følelser og affekter.

Malinowskis serielle værk er et katalog over, hvad et utal af forskellige mennesker "drømmer" eller "drømte", og montageformen er på denne vis en kortlægning af affekter, som normalt er stigmatiserede og ikke udtrykkes i det offentlige rum. Det er oplagt, at serialiteten har fået et ekstremt udtryk i Google-poesien, hvor et egentlig poetisk subjekt ikke eksisterer, og hvor en tekst kan kreeres af en maskine. Den store danske drømmebog bør da også - ligesom Mortensens og UKONs værker - ses i lyset af den toneangivende amerikanske konceptpoesi, hvis teoretiske hovedværk, Kenneth Goldsmiths Uncreative Writing. Managing Language in the Digital Age (2011), er oversat i uddrag af Pejk Malinowski i Konceptuel poesi (2010). Goldsmith skriver helt i pagt med Malinowskis værk:

Uf Konceptuel litteratur gør absolut ingen krav på originalitet af nogen art. Tværtimod, den benytter sig af bevidst ego- og selvudslettende taktikker og har ukreativitet, uoriginalitet, ulæselighed, appropriation, plagiering, fusk, tyveri og falskneri som sine forskrifter; informationsstyring, tekstbehandling, brug af databaser og ekstreme regelbaserede processer som sine metoder; og den har en ånd af kedsomhed, værdiløshed og næringsløshed. (Goldsmith 2010, 75)

Af andre serielt opbyggede værker, der korresponderer med Goldsmiths ovennævnte ideer om uncreative writing og konceptuel litteratur, kan man nævne Martin Larsens otte bind og 5.600 sider lange værk Monogrammer (2008), i hvilke man finder 2,4 millioner lovlige, men dybt bizarre navne af typen: Annavida Henriksen, Sharifa Hjorth, Jeffery Brodersen, Betül Ravn og Yagmur Thøgersen. Blandt kortere, konceptuelt inspirerede, serielt strukturerede danske værker har man Maja Lee Langvads Find Holger Danske (2006), Christian Yde Frostholms Ofte stillede spørgsmål (2008) og Rasmus Graffs Folkets prosa (2010).

Man kan naturligvis med den konceptuelle eller postproduktive poesi diskutere, om der, som Tue Andersen Nexø har anført, blot graves "betydningstomme klichéer" og "alskens ligegyldigheder" op (Nexø 2011, 4 og 6). Noget sådant kan man i hvert fald hævde, hvis man insisterer på, at konceptuelle, serielle tekster som UKON's, Mortensens og Malinowskis skal vurderes på de samme præmisser som anden digtning, idet traditionelle krav om originalitet og koncentration i udtrykket på ingen måde er opfyldt. Modsat kan man anføre, at de tre serielle og flerstemmige tekster får rejst nogle sociale og politiske problemstillinger på en måde, som kun 
den gode kunst kan, ved at lade os sanse og opleve de sociale affekter i form af en overdosering af angstsymptomer eller drømme.

\section{Serielyrik i det enkelte værk som en helhed}

Når vi taler om, at et digterisk værk eller en digtsamling kan have en seriel komposition, er det vigtigt, at slå fast, at der er en anden mulighed, som står i modsætning til det serielle, nemlig det sekventielle. Mens det serielle står for en tilfældig orden, er sekvensen udtryk for en ordning af elementer i forhold til en overordnet idé eller et samlende princip. I Rosenthals og Galls The Modern Poetic Sequence (1983) defineres "the modern sequence" som "a grouping of mainly lyric poems and passages, rarely uniform in pattern, which tend to interact in an organic way" (Rosenthal 1983, 9). Som modsætning til dette har vi imidlertid den serielle orden, som Joseph M. Conte bestemmer og diskuterer i Unending Design:

6f The discontinous elements of the series [...] are rather more atomistic or molecular than plantlike in their behavior. It would be impossible to dispense with continuity among the parts of an organic structure [...] The sections of a series are not hierarchical. There is no initiation, climax, or terminus precisely because there can be no development. In the sequence, the reader must, so to speak, enter through the front door and exit through the rear; but in a series, such as Robert Duncan's Passages, the reader is encouraged to select any of these "passages" as an entrance. (Conte 1991, 22-23)

I praksis kan vi altså lokalisere sekvensen som struktureringsprincip i digtsamlinger, når de enkelte dele af værket har en motiveret og "organisk" placering i dette. Der skal, som Barbara Hernnstein Smith udtrykker det i Poetic Closure. A Study of How Poems End (1968), være tale om, at "sequences are generated by an extra literary principle of succession" (Smith 1968, 110). Populært sagt har et værk, hvis tre første dele hedder "Forår", "Sommer" og "Efterår", selvfølgelig på forhånd fastlagt titlen på og temaet i sin sidste del.

Litteraturhistorisk er sekvensen det altdominerende kompositionsprincip fra Oehlenschlägers Digte 1803 og Baudelaires Fleur du mal (1855) til Rilkes Duineser Elegien (1922) og T.S. Eliots Four Quartets (1935-42). I den sene nordiske modernisme findes det sekventielle dog også i udbredt grad. Det gælder ved brugen af lyriske storformer som Paul Anderssons Elegi över en förlorad sommar (1956-57), Thorkild Bjørnvigs Ravnen (1968), Paal Brekkes Roerne fra Itaka (1960) og Inger Christensens Sommerfugledalen (1991). Men det gælder også i talrige poetiske værker med kortdigte, hvor rækkefølgen af digtene i en samling følger en logik med en række indledende poetologiske digte, efterfulgt af en nogle alment civilisationskritiske og afsluttet med en række mere personlige digte, som det ses i så forskellige digtsamlinger som Tom Kristensens Fribytterdrømme (1920), Rifbjergs Konfrontation (1960) og Pia Tafdrups Dronningeporten (1998).

Forestillingen om, at såvel digtet som digtsamlingen repræsenterer et afrundet og autonomt værk, er da også en grundforestilling i store dele af den symbolistiskmodernistiske og centrallyriske poesitradition. Et markant eksempel på dette er 
Søren Ulrik Thomsens forfatterskab, i hvilket forestillingen om digtet som en slags uafhængig organisme er en gennemgående opfattelse. Dette udtrykkes både i hans minimalistiske poetik, Mit lys brænder (1985), hvor det hedder, at et digt ikke må kunne "fortsætte efter sin sidste linie" (Thomsen 1985, 27), og i hans mere metafysisk orienterede poetik En dans på gloser (1996), hvor en passage lyder: "I det hele taget anlægger jeg på alle niveauer afsluttethed som kriterium; et digt skal kunne stå i sig selv" (Thomsen 1996, 11).

I opposition til dette har vi i en markant dansk avantgardistisk og interaktionslyrik strømning fra de sidste årtier et syn på poesien, hvor faste opfattelser af komposition, værk og genre fornægtes, og hvor det sekventielle er forladt til fordel for det serielle i værkernes opbygning. I den følgende formulering opponerer og polemiserer Peter Laugesen mod, hvad han kalder, "det store, rene, klassiske, dybe digt":

6f Litteraturen er blevet traditionel og indelukket en gang til. Man tør ikke se i øjnene, at en bog, der eventuelt virker ufærdig og uafrundet, måske netop skal være det for at være dén bog. For i det øjeblik man opgiver idéen om et digt eller en bog som en afrundet, klassisk definerbar enhed eller helhed, så går der huller i det, og så kan hvadsomhelst være et digt eller en bog. Og det er dér, jeg gerne vil hen. (Knudsen 1997, 155)

En tilsvarende udtalelse fra digteren Peter Nielsen lyder: "Et digt er nogen gange kun et digt, fordi man, digteren, postulerer at det er et digt. Der er ingen grænser" (Nielsen og Serup 2003, 2).

Lad os se nærmere på indholdet af de to ovennævnte serielyrikere, Laugesens og Nielsens, værker. Peter Laugesen er ganske præcist af Lars Bukdahl blevet kaldt 'føljetonlyriker'. Laugesen har siden slutningen af 1960'erne næsten hvert år udgivet en digtsamling, der har et så tydeligt fællespræg med hans andre værker og en så stor åbenhed i sin komposition, at det kan være rimeligt at anskue forfatterskabet som en gigantisk, uafsluttet digtsamling. Ligesom Laugesens digtsamlinger ofte ikke er til at skelne fra hinanden og fremstår som dele af en 'serie', så har hver af digtsamlingerne en vilkårlig komposition, hvor der ikke er hoved og hale i rækkefølgen af digtene.

Poetikken består kort sagt i, at alle mulige typer af tekster skal have adgang til hans bøger, og at der heller ikke må anlægges nogen æstetiske kvalitetskriterier eller må være nogen gennemgående principper med hensyn til komposition, stil eller temaer i Laugesens værker. "Den regelbundne kunst er en / vederstyggelighed", står der i Laugesens digtsamling Traveling (2017). At der udtrykkes en afstandstagen til en patosladet og metafysisk orienteret værkæstetik, kan ligeledes aflæses i Laugesens digtsamlingstitler, der f.eks. lyder Pjaltetider (1997), Når engle bøvser jazz (1998), Trashpilot (2000), Helt alene i verden og hip som ind i helvede (2001), De sagde hans hund havde lopper (2010) og Der er ingen til stede kun ordene i flok som dyr på vej (2014).

Emnerne skifter uophørligt i Laugesens serielle værker: Oscar Wildes død på en bøssebar i Frankrig, Laugesens skoletid, Jesus med Arafat på himlen over Betlehem, Dan Turèlls gravsten, cykelløb i Sankt Pauli, Elvis, Campusvej, rokoko, Goethe, bluser, gåture i Brabrand, Hölderlin, Juventus, Country Joe, Mols, Zimbabwe, Anden 
Verdenskrig, Twiggy, sko, Hitler, internettet, lange underbukser, B\&O, folkedans, alderdommen, Laugesens hunds $\mathrm{d} ø \mathrm{~d}-\mathrm{og}$ utallige andre emner. Tilsvarende skiftes der hele tiden tonefald og stemningsleje inden for Laugesens værker, hvor vi på få sider kan glide fra det vrede og sarkastiske over det resignerede og melankolske til det muntre og pjankede. I alt består hans værker - og hans forfatterskab som helhed - af en uophørlig række af tekster, der svinger uforudsigeligt mellem nøgtern skrifttematik, underfundig hverdagsrapportering, politisk-social indignation, vild fantaseren og barok humor.

Fokuserer man på et enkelt værk, har man i Traveling (2017) en rodekasse med 150 digte, hvis eneste tematiske ledetråd fra titlen synes at være, at teksterne foregår, mens digteren er på farten i Athen, Damaskus, Thorshavn, Cork samt ikke mindst i det danske land, som det betragtes fra toget. Alt er dog uden orden og overordnet perspektiv, og rejsedigtgenren, der er traditionelt er fyldt med patos og visionære syner, punkteres af digteren på følgende måde i et digt fra antikkens ædle stad: "Athen / Gæs / i bur / i parken / med grimt / klippede vinger / Skønne / vilde / dyr". Og kort efter præsenteres man for det følgende lakoniske hverdagslige 'rejsedigt': "Jeg savner mine venner / En for en / som klip på et buskort / er de forsvundet". En anden digttype, som er placeret klos op af de førnævnte, er de poetologiske digte, hvor der refereres til andre kunstnere som i den følgende elegante parafrase af en definition på kubisme: "Kubismen / iflg. / Gertrude Stein: / Det helt lille barn / ser på sin mors ansigt / helt tæt på / en lille del ad gangen” (Laugesen 2017, 44, 108, 65).

Til forskel fra Peter Laugesens serielle strategi, hvor et utal af vidt forskellige tekster følger efter hinanden, er Peter Nielsen - som den ovennævnte poetologiske formulering viser - ikke særlig interesseret $i$ at skrive enkelttekster, men $i$ at lave surrealistisk automatskrift, hvor alt indkorporeres. Der foregår på denne vis et markant opgør med værkbegrebet. I stedet er det serielle, anskuet som en uafgrænselig og fortløbende strøm af digte og digtsamlinger, matricen i Peter Nielsens forfatterskab. I digtsamlingen Tider (2017) møder vi, som i digterens seneste halve snes bøger, over 150 sider et associativt flow af billeder og snapsnots af virkeligheden, der farer forbi med rasende fart i lange sætninger:

Uf Jeg spørger en jeg møder med en spids hue og en grotesk stor pose af toiletgrej, hvorfor åen løber den modsatte vej i dag.

Overfladerne er smykket med historier om lægegerninger, timerne i døgnet, dyder, farmaceutiske redskaber og planeter.

Jeg åbner en ny, knirkende låge i dag og smider et par granatæbler efter de mange fremadstormende hunde. (Nielsen 2017, 58)

I hver af de tre sætninger kommunikeres oplevelser af uoverskuelighed, uro og utilpassethed. Billederne er som oftest hos Nielsen både originale og sanseappellerende. Samtidig oplever man i Tider, at man ikke har nogen anelse om, hvor associationsstrømmen af serielle billeder fører hen, og hvad meningen er med den.

Den bedste måde at læse Peter Nielsens Tider på er derfor nok det, som Klaus Høeck har kaldt "huglæsningen", hvor man koncentrerer sig om de enkelte tekst- 
passager frem for at forsøge at koncipere værket som en helhed, der skal læses fra den ene ende til den anden. Den eneste sandhed, man finder i Nielsens værk er, at der ikke findes nogen overordnet forståelsesramme for tilværelsen, og værket korresponderer på denne vis med Rosenthals og Galls, Hernnstein Smiths og Contes ideer om, hvad der kendetegner et værk, der afviger fra en sekventiel komposition. En præcis formulering af dette lyder: "Efter min deltagelse i indsamlingen til et nyt verdensbillede / tog jeg ud i skoven for at betragte statuen, som de vindfældede / træer netop havde åbenbaret. Jeg ledte efter dig men fandt kun / bundter af nøgternhed" (77). Et godt bud på, hvad "du" her kan betyde, kunne være en overordnet mening med tilværelsen.

Hvad angår Nielsens holdning til personer med en helhedstolkning af tilværelsen, er det næppe heller tilfældigt, at et af samlingens mest effektfulde digte handler om en præst, som absolut ikke fremstår i noget glorværdigt lys: "Du ser at der er en strenghed men ingen fred / til stede i hans ansigt, det er som om han konfliktfyldt / og uroligt strækker sig ud over sin evne efter små, frosne objekter / på en hylde langt, langt tilbage i sit sind og forsøger at holde dem / frem for os som ting, han foregøgler sig at vi netop har efterspurgt" (29). Der er således masser af kritik af såvel æstetiske, etiske og religiøse pegepinde hos Peter Nielsen.

Nielsens serielle poetik er dog - ligesom Laugesens - ikke udtryk for en tænkning, der forholder sig nihilistisk til digtningens værdi. Det er blot ikke en poesi, der gestaltes ved ideologiske overbygninger, principper og faste ideer om, hvordan tingene hænger sammen, men som tværtimod opstår ud af ingenting som mirakler. Noget sådant fremgår i de eksplosive momenter i Nielsens digtning, hvor man ser to sansninger og refleksioner sat sammen, så en mægtig gnist springer. Man oplever her øjeblikke, som ingen har haft opmærksomheden henledt på i virkelighedens verden, og som derfor står desto stærkere og mere effektfuldt. Et digt blotlægger en forunderlig interaktion mellem et akvarium og et trafiklys:

Uf I stuevinduet der for længst er glemt af blikke står et stort, algegrønt akvarium med udsigt ned til gadekrydset. Stimefiskene deri føler sig tiltrukket af trafikken, de bremser op, står stille og violette i vandet når lyskrydset skifter til rødt. (26)

Serialiteten, forstået som et gentagelsesprægede, kontinuerte og arbitrære forløb af tekst, er med andre ord et grundvilkår i moderne digtning. Ser man på nyere dansk digtning, er den tydelig i iterativt strukturerede værker af digtere som Inger Christensen, Klaus Høeck, Per Aage Brandt, Viggo Madsen, Thomas Boberg, Morten Søndergaard, Ursula Andkjær Olsen, Martin Glaz Serup, Olga Ravn, Caspar Eric, Lone Aburas, Nikolaj Zeuthen, Pejk Malinowski, Majse Aymo-Boot, Signe Gjessing, Josefine Graakjær Nielsen og talrige andre. Dertil kommer forfatterskaber som Laugesens og Nielsens, hvor der ikke er tale om stramme systemer, men hvor teksten fremtræder som en uendelig strøm eller serie. Jeg har i Drømme og dialoger (2009) fremhævet, at forfatterskaber som Klaus Rifbjergs, Jørgen Gustava Brandts, Marianne Larsens, F.P. Jacs og Simon Grotrians er karakteristiske ved, at de høj- 
frekvente udgivelser ofte ikke adskiller sig fra hinanden. På samme måde har Dan Ringgaard i Nordbrandt (2005) påpeget, at denne forfatter i sin poesi arbejder med mobiler, hvor stiliserede motiver, ritualiserede bevægelser og slidte metaforer hele tiden varieres og gentages.

\section{Serielyrik som en ræklke af værker}

I alle de ovennævnte digteres værker er det karakteristisk, at de enkelte digtsamlingers tekster sjældent besidder noget klart fællespræg, og at man kan flytte rundt på digtene mellem de forskellige samlinger af den enkelte forfatter, uden at det ville gøre nogen mærkbar forskel. Man kan kort og godt slå fast, at talrige digtere i samtiden ikke lægger vægt på en fast, ideologisk funderet komposition og heller ikke prioriterer en afgrænsning af de enkelte værker i deres forfatterskab. Dette leder frem til det tredje niveau, hvorpå man kan tale om en serielyrisk tendens, nemlig $\mathrm{i}$ forhold til en række værker fra det samme forfatterskab.

Hvis vi anskuer den lyriske genre i forhold til andre genrer, er det evident, at den serialiserende tendens ikke er så voldsom som ved nogle af de mere kommercielt orienterede genrer som kærligheds-, krigs- og krimifortællingen inden for såvel bog- som filmmediet. Man finder få egentlige lyrik-serier, når man ser bort fra lyriktidsskrifter og -antologier, og når man alligevel gør det, har det oftest en polemisk pointe i forhold til den centrallyriske traditions insisteren på det autonome og unikke værk som en grundlæggende kategori.

Som eksempler på serialiseringstendensen kan man fremhæve to store lyriske forfatterskaber fra det 20. århundrede, nemlig Ezra Pound og Per Højholt. Helt konkret består de to digteres vigtigste produktion af henholdsvis 116 Cantos, skrevet i perioden 1915 til 1965, og 12 bind i en nummeret Praksis-serie, skrevet fra 1977 til 1996. Fælles for disse omfattende serie-værker er det, at de samtidig med, at de med deres nummerering konnoterer en homogenitet og kontinuitet, også udgør en arbitrær og uendelig række af værker med en mængde forskellige genremarkører og stilarter og et utal af uafsluttede motiver.

I Pounds mægtige værk har en del forskere søgt efter en orden, der kunne give det status af at være sekventielt eller at have et helhedspræg med et overordnet ide- eller formmæssigt koncept. Dette er dog sjældent lykkedes, og P.A. Blackmurs karakteristik i The Double Agent. Essays in Craft and Elucidation (1962) af værket som en rodebunke eller en 'rygsæk' er nok den bedst dækkende:

6f The Cantos are not complex, they are complicated; they are not arrayed by logic or driven by pursuing emotion, they are connected because they follow one another, are set side by side, and because an anecdote, an allusion or a sentence begun in one Canto may be continued in another and may never be completed at all; and as for a theme to be realized, they seem to have only, like Mauberley, the general sense of continuity - not unity which may arise in the mind when read seriatim. The Cantos are what Mr Pound himself called them in a passage now excised from the canon, a rag-bag. (Blackmur 1962, 92) 
Man bemærker imidlertid, at den angelsaksiske nykritiker Blackmur er alt andet end begejstret for den serielle form, som han finder hos Pound. Han opstiller en skarp modsætning mellem det sekventielle som "complex", "arrayed by logic or driven by pursuing emotion", "completed" og "unity", og det serielle som anskues som "complicated", "side by side", "continuity" og "rag-bag". Interessant er det imidlertid, at Blackmur har et skarpt blik for det serielles og det serialiseredes gennemgribende betydning som både et internt træk i den enkelte tekst, et kompositorisk træk ved større tekstsammenhænge og et karakteristika ved en fortløbende række af værker. Den serielle tekststruktur ses såvel i de mindste tekstuelle elementer som i den berømte "Canto XLV", hvor en total civilisationskritik udfoldes i det katalogiske digt med anaforen "with usura", som den ses i verdens måske længste lyrikserie, der udgives over 50 år. Det poundske 'rygsækkoncept' med seriel komposition er kort og godt en motor i dette banebrydende forfatterskab, der som få har været normsættende for det 20. århundredes lyrik.

En pendant til Pound, hvad angår kunstnerisk radikalitet og indflydelse på eftertiden, er Højholt. Hans Praksis-serie er, som Blackmur kunne have anført, præget af skift i stilarter og motiver, og som serie er der intet andet til fælles mellem værkerne end dét, der er helt specifikt for forfatteren Højholt, nemlig hans stil, tone, stemme og livsholdning. Genremæssigt møder man i syv af værkerne tekster, der kategoriseres som lyrik, nemlig Praksis 1: Revolver (1977), Praksis 2: Groteskens område (1978), Praksis 3: Den 64. frokost i det grønne (1978), Praksis 5: Nuet druknet i latter (1983), Praksis 9: Det gentagnes musik (1989), Praksis 10: Manøvrer (1993) og Praksis 11: Lynskud (1995). Tilsvarende er fem af bøgerne i Praksis-serien angivet som fortællinger eller med Højholts egen genrebetegnelse "blindgyder", nemlig Praksis 4: Lynmuseet og andre blindgyder (1982), Praksis 6: Salamanderen og andre blindgyder (1986), Praksis 7: Hundekunstneren og andre blindgyder (1988), Praksis 8: Album, tumult (1989) og Praksis 12: Anekdoter (1996). Inden for hvert af disse bind er der desuden - i pagt med serialitetens præmisser - en mangfoldighed af forskellige teksttyper, der både rummer iterative strukturer og er ordnet i serier med digtnumre, der f.eks. handler om alle mulige emner fra Supermule (Praksis 1: Revolver) til pyramider (Praksis 2: Groteskens område).

Samlende kan man om Højholts forfatterskab sige, at det udgør en mægtig matrice af greb, hvad angår opbruddet fra det autonome og unikke centrallyriske digt med dets sakrale aura, og at en hovedstrategi, hvad angår dette opgør, udmøntes i det serielle og det serialiserede. For det sidstes vedkommende har det dog foreløbig kun ført til få egentlige danske lyrik-serier. I forlængelse af Højholts nummererede Praksis-serie har vi f.eks. set Martin Glaz Serups fjerde digtsamling med titlen 4 (2005), Thomas Bobergs digtsamlingsserie Hesteæderne 1-3 (2010-2005), Simon Grotrians Fire (1990) og Ti (1998) samt - med korrelation til blindgyderne - Peter Adolphsens Små historier 1 og 2 (1996 og 2000).

Serialiseringstendensen kan dog også som nævnt knyttes til det faktum, at en stor del af samtidens poeter udgiver deres digte i en lang kontinuert strøm, og at man i langt mindre grad end tidligere skelner mellem de enkelte værker. Der er med Bukdahls humoristiske betegnelse tale om 'føljetonlyrik' eller med denne artikels betegnelse serielyrik. 


\section{Læsningen af serielyrik}

Det serielle og serialiserede er en æstetisk praksis, hvis konsekvenser rækker langt ud over det formelle eksperiment. Der er tale om en poetologisk tænkning, hvor traditionelle forestillinger om, hvad et digt, en digtsamling, et værk og et forfatterskab er, dekonstrueres. Dette betyder, at vi ikke længere problemløst kan tage det enkelte digt eller den enkelte digtsamling som udgangspunkt for en læsning af poesien.

Serielyrikken udfordrer hermed litteraturforskningen med hensyn til den analytiske strategi, der anlægges i læsningen af den. Den værkcentrerede læsning er, hvad enten det gælder et nærsynet fokus på det enkelte digt eller på digtsamlingen som helhed, en hindring for, at en læsning af forfatterskaber, som de mange samtidige, der har været omtalt i denne fremstilling, kan foregå optimalt. Som det skulle være fremgået, er en afgørende bestræbelse i læsningen af serielyrik, at der skabes en produktiv interaktion mellem den æstetiske detalje og et forfatterskabs overordnede koncept.

Blandt de vigtigste forgængere i denne tekstlæsningsstrategi kan nævnes Erich Auerbachs Mimesis (1946), i hvilken en grundtanke er, at man i teksten skal lokalisere en "ansats", hvis "udstråling" kaster lys over større sammenhænge. Noget sådan er netop vigtigt ved serielyrikken, hvor pointen er at se det essentielle i en enorm tekstmængde gennem et udvalgt uddrag, som nærlæses. Blandt andre analytisk frugtbare metodiske overvejelser kan man nævne Johan Fjord Jensens “Tekst og helhed" (1965), hvor han fremhæver, at tekstanalysens mål er at bestemme en "stilholdning", der "slår ud i alle værkets enkeltelementer og igennem utallige relationer fastholder dem til en helhed" (Jensen 1981, 28), og Horace Engdahls tanker fra Beröringens ABC (1994), hvor der tales om litteraturens "stemme" som en intentionel kraft, der gennemstrømmer en forfatters tekster.

De ovennævnte analytiske vinkler, der er blandt lyrikanalysens vigtigste, har imidlertid ligget noget i dvale i de seneste år, hvor retninger som Cultural Studies, køns- og queer-studier, verdenslitterære studier, affektstudier eller autofiktionsforskning kun i ringe grad har haft fokus på stilistiske træk, kompositionelle forhold og genreforhold i samtidslyrikken. Meget tyder dog på, at en forandring af det litteraturvidenskabelige fokus er på vej. I hvert fald er der ingen tvivl om, at serielyrikken i fremtiden vil have en voksende betydning, der vil lægge op til mange udbytterige studier.

\section{Litteratur}

Allen, Rob \& Thijs van den Berg (eds.) (2014): Serialization in Popular Culture, New York: Routledge. Auerbach, Erich (1946): Mimesis. Dargestellte Wirklichkeit in der abendländischen Literatur, Bern:

Franke Ag. Verlag.

Barthes, Roland (1972): Critical Essays, Evanston: Northwestern University Press.

Benjamin, Walter (1998): “Kunstværket i dets tekniske reproducerbarheds tidsalder”, i Kulturkritiske Essays, København: Gyldendal.

Blackmur, Richard P. (1935): The Double Agent: Essays in Craft and Elucidation, New York: Arrow Editions.

Bürger, Peter (1974): Theorie der Avantgarde, Frankfurt am Main: Suhrkamp. 
Conte, Joseph M. (1991): Unending Design. The Forms of Postmodern Poetry, New York: Cornell University Press.

Derrida, Jacques (1970): Om grammatologi (1967), København: Universal Trykkeriet A/S.

Eco, Umberto (1990): "Interpreting Serials" i The limits of interpretation, Bloomington: Indiana University Press.

Eco, Umberto (2009): The Infinity of Lists, New York: Rizzoli.

Engdahl, Horace (1994): Beröringens ABC. En essä om rösten i litteraturen, Stockholm: Bonniers.

Frank, Niels (1993): Yucatán. Essays og andre forsøg, København: Gyldendal.

Friedrich, Hugo (1987): Strukturen i moderne lyrik (1956), København: Gyldendal.

Jensen, Johan Fjord (1981): “Tekst og helhed” (1965) i Efter guldalderkonstruktionens sammenbrud, Aarhus: Modtryk.

Kjærstad, Jan (1997): Menneskets felt, Oslo: Aschehoug.

Knudsen, Peter Øvig (1997): Børn skal ikke lege under fuldmånen. Forfattersamtaler, København: Gyldendal.

Hernnstein Smith, Barbara (1968): Poetic Closure. A Study of How Poems End, Chicago, London: University of Chicago Press.

Larsen, Peter Stein (2009): Drømme og dialoger. To poetiske traditioner omkring 2000, Odense: Syddansk Universitetsforlag.

Larsen, Peter Stein (2015): Poesiens ekspansion. Om nordisk samtidsdigtning, Hellerup: Spring.

Laugesen, Peter (2017): Traveling, København: Gyldendal.

Malinowski, Pejk (2010): Den store danske drømmebog, København: Basilisk.

Mortensen, Audun (2009): alle_forteller_meg_hvor_bra_jeg_er_i_tilfelle_jeg_blir_det, Oslo: Flamme Forlag.

Nexø, Tue Andersen (2011): "Posthistoriske dokumenter. Om poetisk konceptualisme og synet på litteraturhistorien hos nutidens avantgarde" i Vagant 2.

Nielsen, Peter (2017): Tider, København: Gyldendal.

Nielsen, Peter og Martin Glaz Serup (2003): "Hvis det skal handle om poesi, skal det også handle om noget andet". www.nypoesi.net

Nilsson, Ulf Karl Olov (UKON) (2009): Barndomstolen, Stockholm: Norstedts.

Rosenthal, M.L. \& Gall, Sally M. (1983): The Modern Poetic Sequence, Oxford: Oxford University Press 1983.

Ringgaard, Dan (2005): Nordbrandt, Aarhus: Aarhus Universitetsforlag.

Thomsen, Søren Ulrik (1985): Mit lys brænder. Omrids af en ny poetik, København: Vindrose.

Thomsen, Søren Ulrik (1996): En dans på gloser - eftertanker om den kunstneriske skabelsesproces, København: Vindrose 1996.

Turèll, Dan (1973): Karma Cowboy, København: Gyldendal. 